A Comparison of Landsat 8 Operational Land Imager and Provisional Aquatic Reflectance Science Product, Sentinel-2B, and WorldView-3 Imagery for Empirical Satellite-Derived Bathymetry, Unalakleet, Alaska

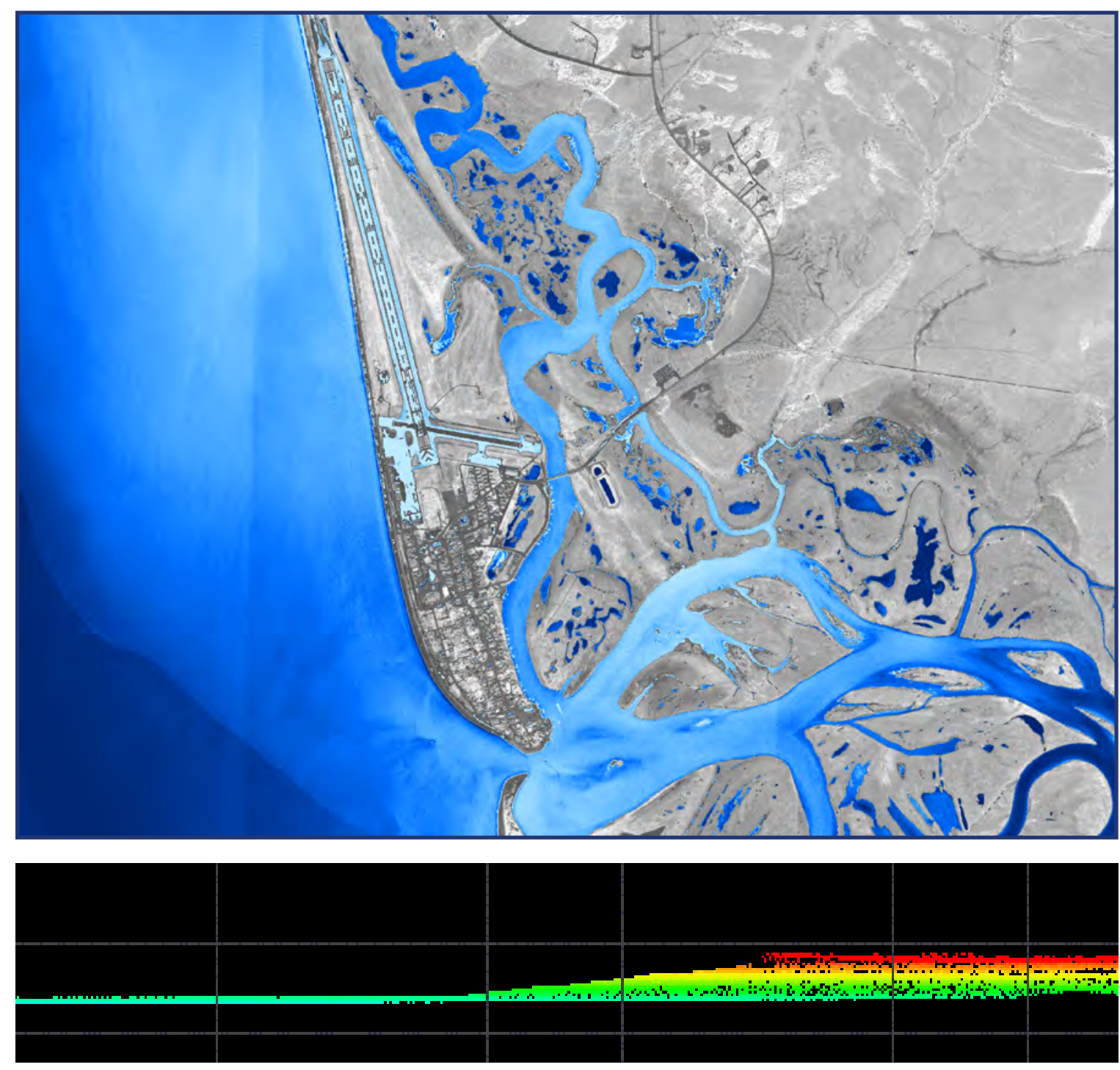

Scientific Investigations Report 2021-5097 


\section{Cover:}

Top, DigitalGlobe WorldView-3 Level-2A satellite imagery infrared band acquired on July 7, 2019, with satellite-derived bathymetry calibrated to light detection and ranging (lidar) data.

Bottom, Lidar point cloud data from the Coastal Zone Mapping and Imaging Lidar (CZMIL) system acquired July 13, 2019. Image credit: U.S. Army Corps of Engineers, Joint Airborne Lidar Bathymetry Technical Center of Expertise. 


\section{A Comparison of Landsat 8 Operational Land Imager and Provisional Aquatic Reflectance Science Product, Sentinel-2B, and WorldView-3 Imagery for Empirical Satellite-Derived Bathymetry, Unalakleet, Alaska}

By Sandra K. Poppenga and Jeffrey J. Danielson

Scientific Investigations Report 2021-5097 


\section{U.S. Geological Survey, Reston, Virginia: 2021}

For more information on the USGS - the Federal source for science about the Earth, its natural and living resources, natural hazards, and the environment—visit https://www.usgs.gov or call 1-888-ASK-USGS.

For an overview of USGS information products, including maps, imagery, and publications, visit https://store.usgs.gov/.

Any use of trade, firm, or product names is for descriptive purposes only and does not imply endorsement by the U.S. Government.

Although this information product, for the most part, is in the public domain, it also may contain copyrighted materials as noted in the text. Permission to reproduce copyrighted items must be secured from the copyright owner.

Suggested citation:

Poppenga, S.K., and Danielson, J.J., 2021, A comparison of Landsat 8 Operational Land Imager and Provisional Aquatic Reflectance science product, Sentinel-2B, and WorldView-3 imagery for empirical satellite-derived bathymetry, Unalakleet, Alaska: U.S. Geological Survey Scientific Investigations Report 2021-5097, 15 p., https://doi.org/10.3133/sir20215097.

Associated data for this publication:

Snyder, A.G., Johnson, C.D., Gibbs, A.E., and Erikson, L.H., 2021, Nearshore bathymetry data from the Unalakleet River mouth, Alaska, 2019: U.S. Geological Survey data release, https://doi.org/10.5066/P9238F8K.

ISSN 2328-0328 (online) 


\section{Acknowledgments}

The authors would like to thank the National Oceanic and Atmospheric Administration (NOAA) Office for Coastal Management (OCM) Digital Coast for their Data Access Viewer to download topobathymetric light detection and ranging (lidar) data that were collected by the U.S. Army Corps of Engineers, Joint Airborne Lidar Bathymetry Technical Center of Expertise, and the NOAA Office of Coast Survey for the Raster Navigational and Electronic Navigational Charts.

The authors would also like to thank the U.S. Geological Survey (USGS) Coastal and Marine Hazards and Resources Program for the opportunity to research satellite-derived bathymetry. Thank you to Alex Snyder, Cordell Johnson, Ann Gibbs, and Li Erikson with the USGS Pacific Coastal and Marine Science Center, Santa Cruz, California, for sharing their in situ sound navigation and ranging data. Also thank you to the USGS Earth Resources Observations and Science (EROS) Center for providing satellite imagery download capabilities via EarthExplorer and Land Satellites Data System Science Research and Development, EROS Science Processing Architecture website. 



\section{Contents}

Acknowledgments ……...................................................................................................................

Abstract

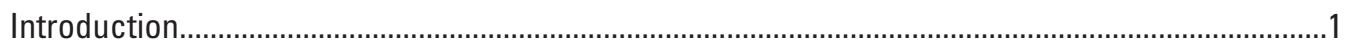

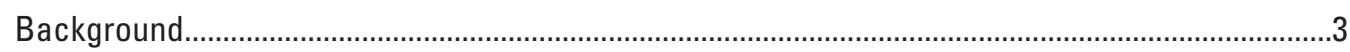

Data Used for Satellite-Derived Bathymetry Research ......................................................................

U.S. Geological Survey Landsat 8 Operational Land Imager Satellite Imagery .........................3

European Space Agency Sentinel-2B Satellite Imagery.........................................................

DigitalGlobe WorldView-3 Satellite Imagery.......................................................................

U.S. Geological Survey Landsat 8 Provisional Aquatic Reflectance Science Product Satellite Imagery ...................................................................................................

U.S. Army Corps of Engineers, National Coastal Mapping Program, Coastal Zone Mapping and Imaging Light Detection and Ranging ..................................................

U.S. Geological Survey, Pacific Coastal and Marine Science Center In Situ

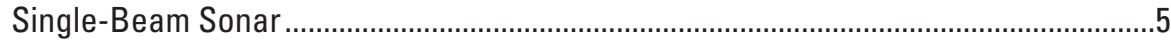

National Oceanic and Atmospheric Administration, U.S. Department of Commerce

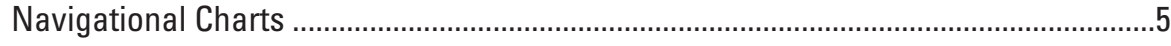

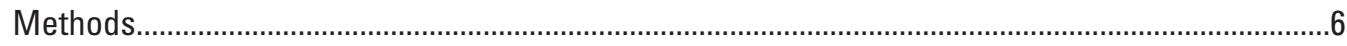

Empirical Logarithmic Ratio Satellite-Derived Bathymetry Method ........................................

Correlation of Vertical Profile Estimates with Topobathy Lidar..................................................

Correlation of Vertical Profile Estimates with In Situ Single-Beam Sonar................................6

Correlation of Vertical Profile Estimate with Electronic Navigational Chart Soundings ..........6

Comparison of Selected Imagery for Empirical Satellite-Derived Bathymetry ..................................7

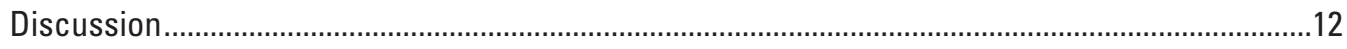

Summary

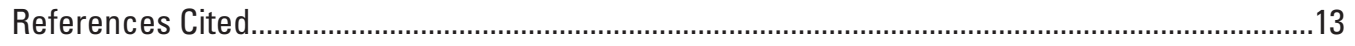

\section{Figures}

1. Map showing geography around Unalakleet, Alaska ......................................................

2. Graphs showing comparison between satellite imagery correlations and

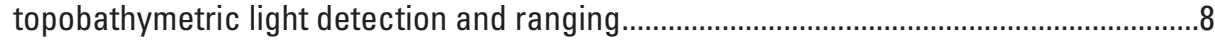

3. Graphs showing comparison between satellite imagery correlations and nearshore single-beam sound navigation and ranging ...................................................

4. Graphs showing comparison between satellite imagery correlations, and nearshore and offshore single-beam sound navigation and ranging.............................10

5. Comparison between satellite imagery correlations and Electronic Navigational Chart soundings......

\section{Tables}

1. Comparison of satellite imagery used in the empirical satellite-derived bathymetry method

2. Comparison of topobathymetric light detection and ranging and single-beam sound navigation and ranging data correlated to satellite imagery band ratios 


\section{Conversion Factors}

International System of Units to U.S. customary units

\begin{tabular}{|c|c|c|}
\hline Multiply & By & To obtain \\
\hline \multicolumn{3}{|c|}{ Length } \\
\hline nanometer (nm) & 0.001 & micrometer $(\mu \mathrm{m})$ \\
\hline centimeter $(\mathrm{cm})$ & 0.3937 & inch (in) \\
\hline meter $(\mathrm{m})$ & 3.281 & U.S. Survey foot (ft) \\
\hline meter $(\mathrm{m})$ & $1 / 0.3048$ & international foot (ft) \\
\hline meter (m) & 1.094 & yard (yd) \\
\hline kilometer (km) & 0.621 & mile (mi) \\
\hline meters per year & 3.281 & feet per year \\
\hline
\end{tabular}

\section{Datum}

Vertical coordinate information for light detection and ranging (lidar) is referenced to the North American Vertical Datum of 1988 (NAVD 88).

Vertical coordinate information for Electronic Navigational Chart soundings is referenced to mean sea level.

Horizontal coordinate information for lidar is referenced to the North American Datum of 1983 (NAD 83), National Spatial Reference System (NSRS) 2007.

Horizontal coordinate information for sound navigation and ranging (sonar) is referenced to the NAD 83, 2011 realization.

Horizontal coordinate information for satellite imagery and navigational charts are referenced to the World Geodetic System 1984 (WGS 84) 


\section{Abbreviations}

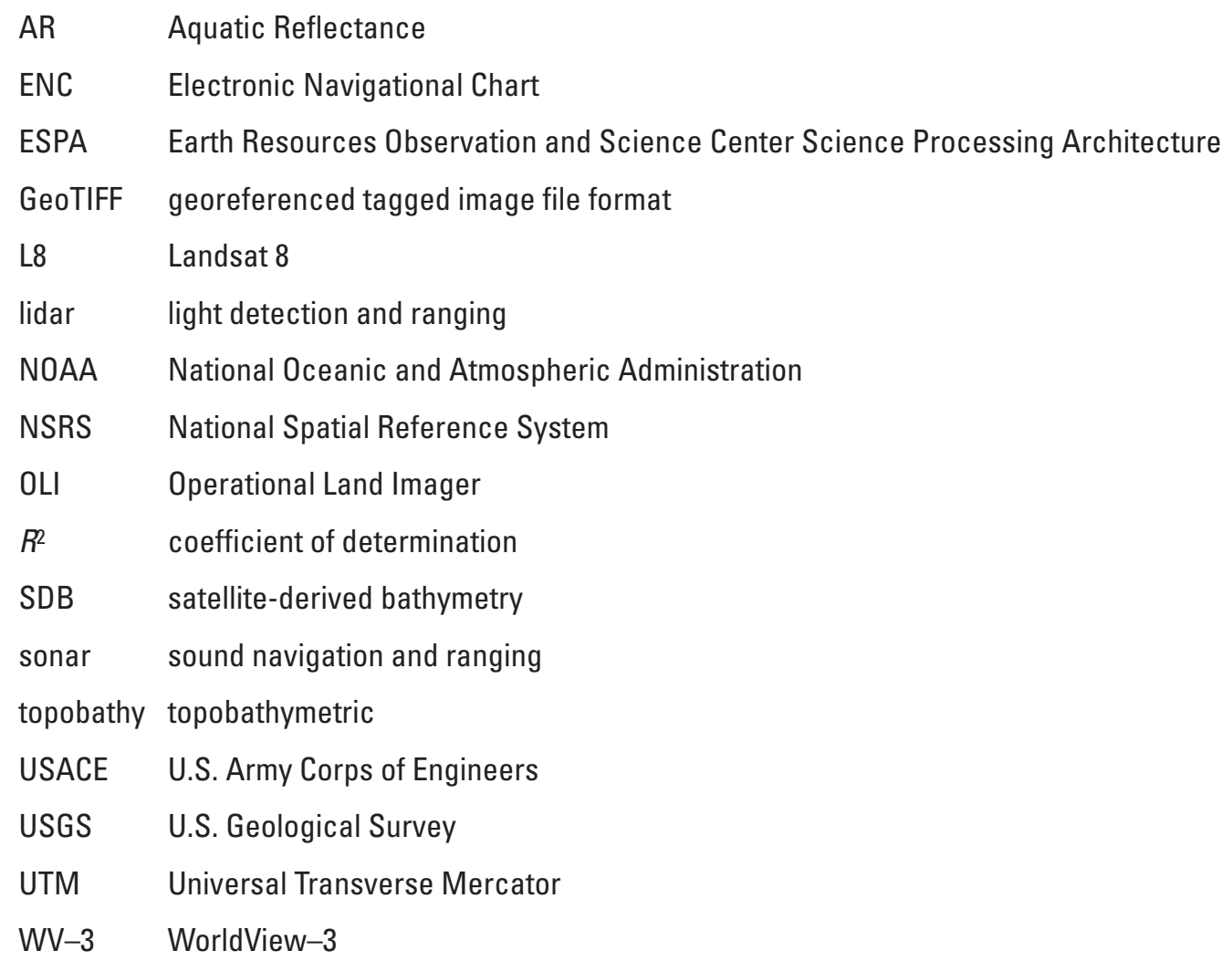





\title{
A Comparison of Landsat 8 Operational Land Imager and Provisional Aquatic Reflectance Science Product, Sentinel-2B, and WorldView-3 Imagery for Empirical Satellite-Derived Bathymetry, Unalakleet, Alaska
}

\author{
By Sandra K. Poppenga and Jeffrey J. Danielson
}

\section{Abstract}

Satellite-derived bathymetry (SDB) based upon an empirical band ratio method is a cost-effective means for mapping nearshore bathymetry in coastal areas vulnerable to natural hazards. This is particularly important for the lowlying coastal community of Unalakleet, Alaska, that has been negatively affected not only by flooding, storm surge, and historically strong storms but also by high erosion rates stemming from the Unalakleet River and Norton Sound. The purpose of this study was to assess the viability of different satellite imagery, including Landsat 8 (L8) Operational Land Imager, Sentinel-2B, WorldView-3, and L8 Provisional Aquatic Reflectance science product, for deriving SDB for Unalakleet, Alaska. Correlations were performed between satellite imagery band ratios and topobathymetric (topobathy) light detection and ranging (lidar) and in situ single-beam sound navigation and ranging (sonar). The satellite imagery correlations with topobathy lidar did not yield as high of a linear relation with water depths as the satellite imagery correlations with the single-beam sonar. An extinction depth, where light no longer attenuates through the water column, was not identified because of the shallow depths within the topobathy lidar and single-beam sonar datasets. Although some single-beam soundings measured at 7 meters deep, the correlations with the SDB band ratios did not yield a strong linear relation. Satellite imagery band ratio correlations with Electronic Navigational Chart soundings did not yield a strong linear relation because of older source data. Less than optimal linear regressions were most likely due to the geography of Unalakleet, Alaska, a low-lying coastal community subject to high erosion rates from surrounding waters. This study is one of the first attempts to compare different satellite imagery band ratio correlations with topobathy lidar and in situ sonar to assess the viability for nearshore SDB for coastal Unalakleet, Alaska.

\section{Introduction}

Low-lying coastal communities are subject to natural hazards, including flooding, storm surge, and sea-level rise. One such community, Unalakleet, Alaska, is also in a geographic location that is already negatively affected by erosion from the Unalakleet River, Norton Sound, and the Bering Sea (fig. 1). Because of high erosion rates, the lack of nearshore bathymetric information has been identified as a critical data gap for inundation and wave runup modeling for coastal Alaskan communities (Patton and Moll-Stalcup, 1996; City of Unalakleet, 2008; Erikson and others, 2015; Snyder and Gibbs, 2019; U.S. Army Corps of Engineers [USACE], 2019; U.S. Geological Survey [USGS], 2020d). Thus, in this research, correlations between remotely sensed imagery band ratios from passive sensors and bathymetric point data from active sensors were assessed to determine which satellite imagery was viable for deriving satellite-derived bathymetry (SDB) for coastal Unalakleet, Alaska.

Remote-sensing platforms that use passive and active sensors have proven viable for estimating nearshore bathymetry with empirical SDB methods (Stumpf and others, 2003; Pe'eri and others, 2016a, 2016b; Poppenga and others, 2018; International Hydrographic Organization, 2019). For example, empirical SDB methods characterize the attenuation of light in the water column from naturally occurring radiation (sunlight) using satellite imagery from passive sensors aboard spaceborne platforms. However, empirical SDB methods require ancillary data that are referenced to a local datum to provide bathymetric depth values for correlation purposes with satellite imagery. The ancillary data are acquired with active sensors that provide their own source of electromagnetic radiation, such as green laser (about 532 nanometers) light detection and ranging (lidar). Both passive sensor satellite imagery and active sensor lidar and sound navigation and ranging (sonar) were used in this study to assess band ratio correlations.

The most common empirical method for deriving SDB is the band ratio-based technique, or the natural logarithm approach (Stumpf and others, 2003; Legleiter and others, 


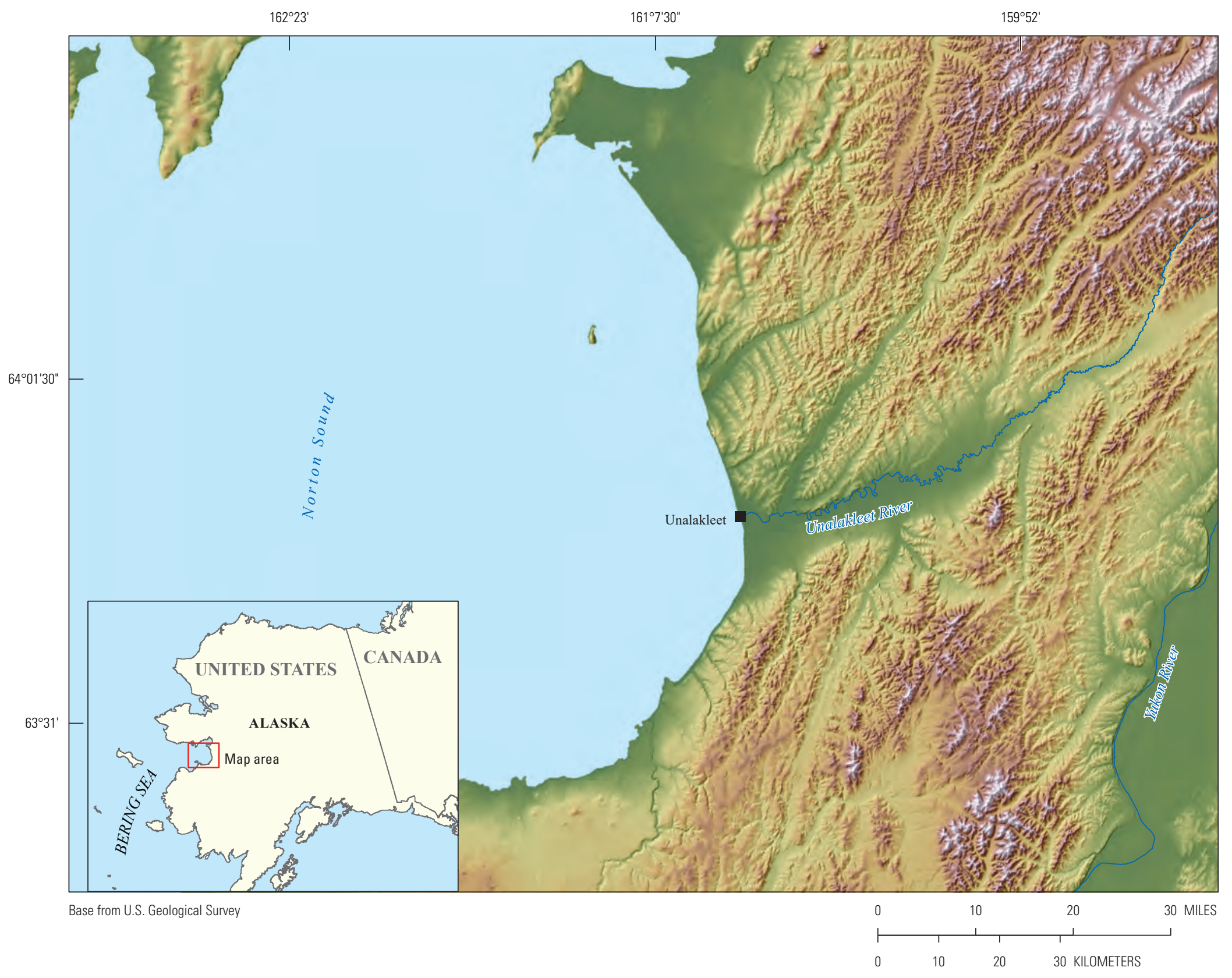

N

产

Figure 1. Geography around Unalakleet, Alaska. 
2009; Legleiter and Overstreet, 2012; Pe'eri and others, 2016a, 2016b; International Hydrographic Organization, 2019). The band ratio method was applied to Landsat 8 (L8) Operational Land Imager (OLI), L8 Provisional Aquatic Reflectance (AR) science product, Sentinel-2B, and WorldView-3 (WV-3) satellite imagery for the Unalakleet, Alaska, area (USGS, 2019a, 2019b, 2019c, 2020a, 2020b, 2020c) to compare correlations with green laser lidar (National Oceanic and Atmospheric Administration [NOAA], 2019a) and in situ single-beam sonar (Snyder and others, 2021). This study is one of the first attempts to compare different satellite imagery band ratios correlated with topobathymetric (topobathy) lidar and in situ single-beam sonar to assess the viability for nearshore SDB in the context of the low-lying coastal Unalakleet, Alaska, community vulnerable to natural hazards.

\section{Background}

In the west-central part of Alaska lies the coastal Native Village of Unalakleet that is next to the Norton Sound of the Bering Sea at the mouth of the Unalakleet River (fig. 1). The region has a subarctic climate with maritime influences that frequently affect the coastal communities next to the Bering Sea with historically strong storms. Situated near the end of a low-lying sand and gravel spit of unconsolidated and poorly consolidated surficial deposits on the mainland Alaska, this coastal community is vulnerable to storm-surge, wave runup, coastal flooding, coastal erosion, and sea-level rise (Patton and Moll-Stalcup, 1996; USACE, 2006, 2019; City of Unalakleet, 2008; Erikson and others, 2015; Wilson and others, 2015; Snyder and Gibbs, 2019).

Information about shallow waters surrounding the Unalakleet low-lying sand and gravel spit is needed because the community is negatively affected by erosion from the Unalakleet River (averaging as much as 0.61 meter per year) and storm surge originating from the Bering Sea and Norton Sound (averaging as much as 0.3 meter per year) (City of Unalakleet, 2008; USACE, 2006, 2019). The erosion could affect the sustainability of infrastructure, including a water line running along the Norton Sound and some parts of the Unalakleet airport (USACE, 2006, 2019).

Erosion and susceptibility to storm surge flooding compounded by low-lying elevations surrounding Unalakleet, Alaska, led to nearshore bathymetric research for this coastal area. An empirical band ratio SDB method was applied to L8 OLI, L8 Provisional AR, Sentinel-2B, and WV-3 imagery to assess how different satellite imagery correlates with topobathy lidar and single-beam sonar for deriving profile depth estimates that can be integrated with high-resolution elevation (topography), such as topobathy digital elevation models developed by the USGS Coastal National Elevation Database project (Danielson and others, 2016; Thatcher and others, 2016).

\section{Data Used for Satellite-Derived Bathymetry Research}

This section of the report describes the data used for the satellite-derived bathymetry research. The data included L8 OLI, Sentinel-2B, WV-3, and L8 Provisional AR imagery; lidar data; in situ single-beam sonar; and electronic navigational charts.

\section{U.S. Geological Survey Landsat 8 Operational Land Imager Satellite Imagery}

The L8 OLI Level-1, 16-bit, relatively cloud-free multispectral imagery acquired at nadir on April 24, 2019, was downloaded from USGS EarthExplorer in georeferenced tagged image file format (GeoTIFF) format in Universal Transverse Mercator (UTM) Zone 4 North projection (USGS, 2019b) (table 1). The L8 satellite orbits the Earth at an altitude of 705 kilometers $(\mathrm{km})$ imaging a swath width of $185 \mathrm{~km}$ in a sun-synchronous, near-polar orbit, and has a revisit frequency of 16 days. The 30 -meter $(\mathrm{m})$ horizontal resolution, multispectral bands used in this research were blue band 2 $(0.45-0.51$ micrometer $[\mu \mathrm{m}])$, green band $3(0.53-0.59 \mu \mathrm{m})$, and the shortwave infrared-1 band $6(1.57-1.65 \mu \mathrm{m})$. The Landsat satellites have continuously acquired space-based images of the Earth's land surface, providing data that serve as valuable resources for many applications; for example, L8 OLI images contain a deep blue band for coastal areas and shallow water observations that is useful for SDB research (USGS, 2016; Poppenga and others, 2018).

\section{European Space Agency Sentinel-2B Satellite Imagery}

Sentinel-2B, 16-bit, relatively cloud-free multispectral imagery acquired at nadir on July 7, 2019, was downloaded from USGS EarthExplorer in GeoTIFF format in UTM Zone 4 North projection (USGS, 2019c) (table 1). The Sentinel-2B satellite orbits the Earth at a mean altitude of $786 \mathrm{~km}$, imaging a swath width of $290 \mathrm{~km}$, and is part of the European Space Agency Corpernicus Sentinel-2 mission, which consists of a constellation of two sun-synchronous, polar-orbiting satellites with a high revisit time (10 days at the equator with 1 satellite, and 5 days with 2 satellites under cloud-free conditions) (European Space Agency, 2020a). The Sentinel-2B 10-m horizontal resolution, multispectral bands used in this research were blue band 2 (about $0.493 \mu \mathrm{m}$ ), green band 3 (about $0.56 \mu \mathrm{m}$ ), and the near infrared band 8 (about $0.833 \mu \mathrm{m}$ ) (European Space Agency, 2020b). The Sentinel-2B satellites provide 10-m horizontal resolution optical imagery that supports monitoring of vegetation, soil, and coastal areas. 
Table 1. Comparison of satellite imagery used in the empirical satellite-derived bathymetry method.

$[\mathrm{m}$, meter]

\begin{tabular}{|c|c|c|c|c|c|}
\hline Satellite sensor & Imagery type & $\begin{array}{l}\text { Imagery } \\
\text { horizontal } \\
\text { resolution } \\
\quad(\mathrm{m})\end{array}$ & $\begin{array}{l}\text { Imagery acquisition } \\
\text { date }\end{array}$ & $\begin{array}{c}\text { Imagery } \\
\text { acquired at } \\
\text { nadir or off } \\
\text { nadir }\end{array}$ & $\begin{array}{l}\text { Imagery horizontal projection } \\
\text { (and datum) }\end{array}$ \\
\hline $\begin{array}{l}\text { Landsat } 8 \\
\text { Operational } \\
\text { Land Imager }\end{array}$ & $\begin{array}{l}\text { Level-1 precision and terrain } \\
\text { corrected }\end{array}$ & 30 & April 24, 2019 & Nadir & $\begin{array}{l}\text { Universal Transverse } \\
\text { Mercator Zone } 4 \text { North } \\
\text { (World Geodetic System } \\
\text { of 1984) }\end{array}$ \\
\hline Sentinel-2B & Level 1C & 10 & July 7, 2019 & Nadir & $\begin{array}{l}\text { Universal Transverse } \\
\text { Mercator Zone } 4 \text { North } \\
\text { (World Geodetic System } \\
\text { of 1984) }\end{array}$ \\
\hline WorldView-3 & Level 2A & 2 & July 7, 2019 & $\begin{array}{l}19.3^{\circ} \text { off- } \\
\text { nadir-view } \\
\text { angle }\end{array}$ & $\begin{array}{l}\text { Universal Transverse } \\
\text { Mercator Zone } 4 \text { North } \\
\text { (World Geodetic System } \\
\text { of 1984) }\end{array}$ \\
\hline Landsat 8 & $\begin{array}{l}\text { Provisional Aquatic } \\
\text { Reflectance science product } \\
\text { (Level-1 reflective visible } \\
\text { spectral bands) }\end{array}$ & 30 & April 24, 2019 & Nadir & $\begin{array}{l}\text { Universal Transverse } \\
\text { Mercator Zone } 4 \text { North } \\
\text { (World Geodetic System } \\
\text { of 1984) }\end{array}$ \\
\hline
\end{tabular}

\section{DigitaIGlobe WorldView-3 Satellite Imagery}

DigitalGlobe WV-3 Level-2A, 16-bit, multispectral imagery acquired at 19.3 degrees $\left(^{\circ}\right)$ off-nadir-view angle on July 7, 2019, was downloaded from USGS EarthExplorer in GeoTIFF format in UTM Zone 4 North projection (USGS, 2019a) (table 1). The DigitalGlobe WV-3 satellite orbits the Earth at an expected altitude of $617 \mathrm{~km}$ imaging a swath width at nadir of $13.1 \mathrm{~km}$, and has a revisit frequency of less than 1.0 day at $40^{\circ} \mathrm{N}$ latitude and 4.5 days at $20^{\circ}$ off nadir or less (DigitalGlobe, 2016). The WV-3 multispectral bands used in the SDB process were blue band $2(0.45-0.51 \mu \mathrm{m})$, green band $3(0.51-0.58 \mu \mathrm{m})$, and the near-infrared 2 band 8 $(0.86-1.04 \mu \mathrm{m})$. The WV-3 satellite provides highly detailed imagery (about 2-m horizontal resolution) in support of coastal applications.

\section{U.S. Geological Survey Landsat 8 Provisional Aquatic Reflectance Science Product Satellite Imagery}

The L8 Provisional AR science product was downloaded from USGS Earth Resources Observation and Science Center, Science Processing Architecture (ESPA) On-Demand Interface in GeoTIFF format in UTM Zone 4 North projection (USGS, 2020a). The 16-bit, relatively cloud-free multispectral imagery was acquired at nadir on April 24, 2019, at a 30-m horizontal resolution (table 1). The L8 Provisional AR multispectral bands used in this research were blue band 2 $(0.45-0.51 \mu \mathrm{m})$ and green band $3(0.53-0.59 \mu \mathrm{m})$ (USGS, 2020a, 2020b), along with the L8 OLI shortwave infrared band $6(1.57-1.65 \mu \mathrm{m})$ (USGS, 2019b, 2020a, 2020b). The L8 Provisional AR science product is derived from L8 Level-1 reflective visible spectral bands over inland water bodies and nearshore coastal regions. Top of Atmosphere reflectance and auxiliary atmospheric data are input to an atmospheric correction algorithm to retrieve the water-leaving radiance at visible wavelengths (USGS, 2020b). The L8 Provisional AR science product provides the aquatic remote sensing community the capability to map optically active components across inland and nearshore water bodies (USGS, 2020a, 2020b).

\section{U.S. Army Corps of Engineers, National Coastal Mapping Program, Coastal Zone Mapping and Imaging Light Detection and Ranging}

Topobathy lidar of Unalakleet, Alaska, was downloaded from the NOAA Office for Coastal Management, Data Access Viewer in UTM Zone 4 North, North American Datum of 1983 National Spatial Reference System 2007 (table 2). The airborne hydrographic survey was collected on July 13, 2019, by the USACE, Joint Airborne Lidar Bathymetry Technical Center of Expertise using Coastal Zone Mapping and Imaging Lidar at a wavelength of about 532 nanometers. The lidar point data were referenced to the North American Vertical Datum of 1988, height in meters. The Coastal Zone Mapping and Imaging Lidar were compiled to meet 19.6-centimeter vertical accuracy at the 95-percent confidence level (NOAA, 2019a). The Coastal Zone Mapping and Imaging Lidar topobathy lidar data were used as control points for SDB correlation analysis. 
Table 2. Comparison of topobathymetric light detection and ranging and single-beam sound navigation and ranging data correlated to satellite imagery band ratios.

\begin{tabular}{|c|c|c|c|c|c|}
\hline Data & Data type & Acquisition date & Spatial reference & Horizontal datum & Vertical datum \\
\hline $\begin{array}{l}\text { Light detection } \\
\text { and ranging }\end{array}$ & $\begin{array}{l}\text { Green laser (about } \\
532 \text { nanometers) } \\
\text { topobathy lidar clas- } \\
\text { sified as bathymetric } \\
\text { data }\end{array}$ & July 13,2019 & $\begin{array}{l}\text { Universal } \\
\text { Transverse } \\
\text { Mercator Zone } 4 \\
\text { North }\end{array}$ & $\begin{array}{c}\text { North America Datum } \\
\text { of } 1983 \text { (National } \\
\text { Spatial Reference } \\
\text { System of 2007) }\end{array}$ & $\begin{array}{l}\text { North American Vertical } \\
\text { Datum of 1988, height in } \\
\text { meters. }\end{array}$ \\
\hline $\begin{array}{l}\text { Sound naviga- } \\
\text { tion and } \\
\text { ranging }\end{array}$ & Single-beam soundings & July 9-12, 2019 & $\begin{array}{l}\text { Universal } \\
\text { Transverse } \\
\text { Mercator Zone } 4 \\
\text { North }\end{array}$ & $\begin{array}{l}\text { North American Datum } \\
\text { of 1983, } 2011 \text { real- } \\
\text { ization }\end{array}$ & $\begin{array}{l}\text { North American Vertical } \\
\text { Datum of } 1988 .\end{array}$ \\
\hline $\begin{array}{l}\text { Hydrographic } \\
\text { surveys }\end{array}$ & $\begin{array}{l}\text { Raster navigational } \\
\text { chart }\end{array}$ & $\begin{array}{l}\text { 1900-39 } \\
\text { (published } \\
\text { December } 1 \text {, } \\
\text { 2018) }\end{array}$ & Global Mercator & $\begin{array}{l}\text { World Geodetic System } \\
\text { of } 1984\end{array}$ & $\begin{array}{l}\text { Soundings in fathoms } \\
\text { (fathoms and feet to } \\
11 \text { fathoms) at mean } \\
\text { lower low water. }\end{array}$ \\
\hline
\end{tabular}

\section{U.S. Geological Survey, Pacific Coastal and Marine Science Center In Situ Single-Beam Sonar}

Single-beam sonar data of the Unalakleet, Alaska, area were obtained from the USGS Pacific Coastal and Marine Science Center. The sonar survey was collected from July 9, 2019 , to July 12, 2019, with a watercraft equipped with an Odom Echotrac CV-100 single-beam echosounder, with Trimble R7 Global Navigation Satellite System receivers, and with a Trimble Zephyr 3 Global Navigation Satellite System antenna. All sonar data measurements were referenced to North American Datum of 1983, 2011 realization, and vertically referenced to North American Vertical Datum of 1988, height in meters (Snyder and others, 2021) (table 2).

\section{National Oceanic and Atmospheric Administration, U.S. Department of Commerce Navigational Charts}

The NOAA Alaska-west coast, Norton Sound to Bering Strait, Raster Navigational Chart (RNC) 16200 was downloaded from the NOAA Office of Coast Survey interactive chart locator georeferenced in BSB format, a file format that NOAA uses to distribute Raster Navigational Charts (NOAA, 2018) (table 2). The NOAA Electronic Navigational Chart (ENC) US3AK80M for Unalakleet, Alaska, was downloaded from NOAA's Office of Coast Survey ENC interactive chart locator as a geo-referenced database of NOAA nautical chart features and their attributes (NOAA, 2020) (table 2). The RNC and ENC provide an electronic charting system for nautical reference and marine navigation. 


\section{Methods}

This section of the report describes the methods used for the SBD research. The methods include empirical band ratio methods and correlation of vertical profile estimates with topobathy lidar, in situ single-beam sonar, and ENC soundings.

\section{Empirical Logarithmic Ratio Satellite-Derived Bathymetry Method}

An empirical band ratio SDB method, as published by the International Hydrographic Organization, Intergovernmental Oceanographic Commission (International Hydrographic Organization, 2019), was applied to L8 OLI and L8 Provisional AR imagery $(30 \mathrm{~m})$, Sentinel-2B imagery (10 m), and WV-3 imagery ( $2 \mathrm{~m}$ ) in the low-lying Unalakleet, Alaska, coastal area to assess correlations between the attenuation of light in the water column and chart datum derived from topobathy lidar and in situ single-beam sonar.

For each satellite imagery, the infrared band was used to determine an inflection point on a spectral response curve between nearshore water and land. Using only the nearshore water part of the imagery, attenuation of light within the water column was characterized by measuring at-sensor radiance or reflectance at different depths. The water attenuation proportional to depth was based on the ratio of the satellite imagery blue and green observed radiance or reflectance to decipher an extinction depth at which light no longer attenuated through the water column. The band ratio vertical profile depth estimates were derived as shown in equation 1 (Stumpf and others, 2003; Pe'eri and others, 2016a, 2016b; Poppenga and others, 2018; International Hydrographic Organization, 2019).

$$
z=m_{1}\left(\frac{\ln \left(L_{o b s}\left(\lambda_{i}\right)\right)}{\ln \left(L_{o b s}\left(\lambda_{j}\right)\right)}\right)-m_{0}
$$

where

$$
\begin{aligned}
& z \text { is the vertical profile depth estimate, } \\
& m_{1} \text { is the tangent of the slope angle, } \\
& m_{0} \text { is the intercept, } \\
& \ln \text { is the natural logarithm ratio, } \\
& L_{\text {obs }}\left(\lambda_{i}\right) \text { is the observed radiance or reflectance of the } \\
& L_{\text {obs }}\left(\lambda_{j}\right) \text { blue band, and } \\
& \text { is the observed radiance or reflectance of the } \\
& \text { green band. }
\end{aligned}
$$

\section{Correlation of Vertical Profile Estimates with Topobathy Lidar}

Topobathy lidar datasets contain thousands, if not millions, of recorded laser pulses that are classified according to what reflective surface they represent. SDB band ratio correlations do not need millions of points to perform a linear regression; thus, the lidar points that were classified as bathymetric data were subset from the USACE topobathy lidar (NOAA, 2019a) for the Unalakleet, Alaska, area. The band ratio values from each satellite imagery (L8 OLI, Sentinel-2B, WV-3, and L8 Provisional AR) were then combined with the lidar subset attributes, and correlations were performed to derive optical depth for inferring bathymetry, coefficient of determination $\left(R^{2}\right)$, and regression line equations containing the tangent of the slope angle and the intercept (gain/offset) for vertical referencing.

\section{Correlation of Vertical Profile Estimates with In Situ Single-Beam Sonar}

Similar procedures were performed for correlating each satellite imagery (L8 OLI, Sentinel-2B, WV-3, and L8 Provisional AR) vertical profile estimates to in situ singlebeam sonar (Snyder and others, 2021). Parts of the projected sonar dataset were collected beyond the extent of the topobathy lidar collection extent; therefore, two different sonar subsets were created for satellite imagery band ratio correlation assessments. The first sonar subset contained nearshore soundings, whereas the second sonar subset contained nearshore soundings and soundings farther out in the water. The vertical profile estimates for each satellite imagery were then combined with each sonar subset attributes, and correlations were performed providing $R^{2}$ values and regression line equations.

\section{Correlation of Vertical Profile Estimate with Electronic Navigational Chart Soundings}

According to the Alaska-west coast, Norton Sound to Bering Strait Raster Navigational Chart, a digital facsimile of a paper navigational chart, the offshore Unalakleet, Alaska, soundings were collected between 1900 and 1939 (NOAA, 2018). The chart values were converted, by NOAA, to electronic depth values for soundings, depth curves, and other features with depths to populate the ENC database (NOAA, 2019b). Therefore, the most recent ENC soundings available for correlation with SDB vertical profile estimates were dated to the early 20th century. Furthermore, according to the ENC sounding database category zone of confidence attribute, large depth anomalies may be expected (NOAA, 2020). Regardless, available ENC soundings were correlated with each satellite imagery SDB band ratios for comparative correlation purposes. Although the ENC database consisted of point soundings farther west into the Norton Sound, subsets were not needed because the number of points within the nearshore Unalakleet, Alaska, area was small. 


\section{Comparison of Selected Imagery for Empirical Satellite-Derived Bathymetry}

Four correlation comparisons are presented in this paper. The first correlation is between satellite imagery (L8 OLI, Sentinel-2B, WV-3, and L8 Provisional AR) band ratios and topobathy lidar (fig. 2). The second correlation is between satellite imagery band ratios and nearshore in situ singlebeam sonar (fig. 3). The third correlation is between satellite imagery band ratios, and nearshore and offshore in situ singlebeam sonar (fig. 4). The fourth correlation is between satellite imagery band ratios and ENC soundings (fig. 5).

The correlations with topobathy lidar shown in figure 2 have similar linear regression patterns from the $0.0-1.0 \mathrm{~m}$ depth range with slight variations between different satellite imagery at the $0.2-0.8 \mathrm{~m}$ depth range. Beyond about $1 \mathrm{~m}$ depth, all correlations display dispersion extending to about $1.5 \mathrm{~m}$ depth. This supports the finding that the deepest value classified as bathymetric data in the topobathy lidar was about $1.5 \mathrm{~m}$, which is not optically deep enough to define an extinction depth. Optically deep values were farther offshore beyond the extent of the topobathy lidar acquisition. In addition to similar linear regression patterns, the proportion of the variance results also were similar ( $R^{2}$ ranging from 0.7060 to 0.7955) (fig. 2).

In figure 3 , the linear regression patterns for the nearshore in situ single-beam sonar vary slightly between each satellite imagery correlation. The maximum sonar depths on the $\mathrm{x}$-axis range between about 2 and $2.5 \mathrm{~m}$; the lower value was caused by some soundings beyond the $\mathrm{WV}-3$ imagery extent. However, all $R^{2}$ for the nearshore sonar correlations (fig. 3) are higher than the topobathy lidar correlations (fig. 2), particularly for L8 (0.9264), Sentinel (0.8669), and L8 Provisional AR (0.9285) imagery (fig. 3), indicating that the in situ single-beam sonar correlations may provide a more viable correlation for characterizing attenuation of the water column than the topobathy lidar correlations. But the maximum overall depth range for the nearshore sonar correlations was not viable for defining an extinction depth even without a dispersion pattern present.

Additional correlations were performed between the L8 OLI, L8 Provisional AR, and Sentinel-2B SDB band ratios and a single-beam sonar subset, which included nearshore (as much as about $1.5 \mathrm{~m}$ depth) and offshore (as much as about $7 \mathrm{~m}$ depth) in situ soundings. Note that the WV-3 correlation was not performed because the offshore soundings were beyond the extent of the WV-3 imagery selected for this study. The linear regression for L8 OLI and L8 Provisional AR with this sonar subset resulted in a substantial drop in the $R^{2}$ ( 0.0454 and 0.2708 , respectively), whereas the $R^{2}$ for the Sentinel-2B imagery correlation did not drop as much (0.7318) (fig. 4). Regardless, in each correlation, the linear regressions showed similar patterns between 3 and $6 \mathrm{~m}$ with less-than-optimal results.

The final SDB band ratio correlations performed were with ENC soundings (fig. 5). The maximum depth range on the $\mathrm{x}$-axis was between about 13 and $15 \mathrm{~m}$, excluding the WV -3 correlation with only two soundings within the imagery extent. The other three correlations resulted in regression relation with low $R^{2}(0.2341$ to 0.6560$)$ as shown in figure 5 . These results are most likely caused by the timeframe of the sounding collections dating to the early $1900 \mathrm{~s}$. 

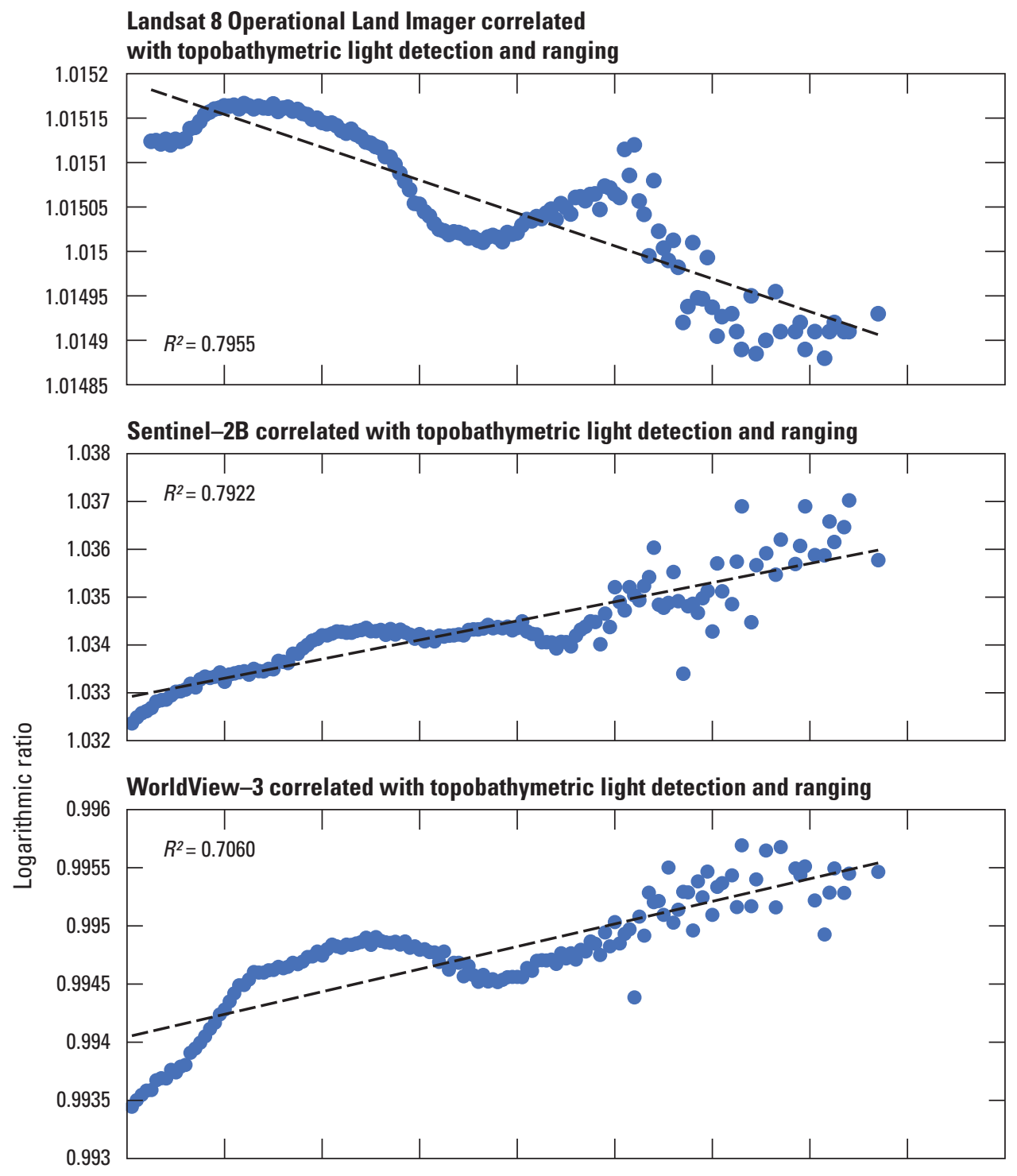

Landsat 8 Provisional Aquatic Reflectance science product correlated with topobathymetric light detection and ranging

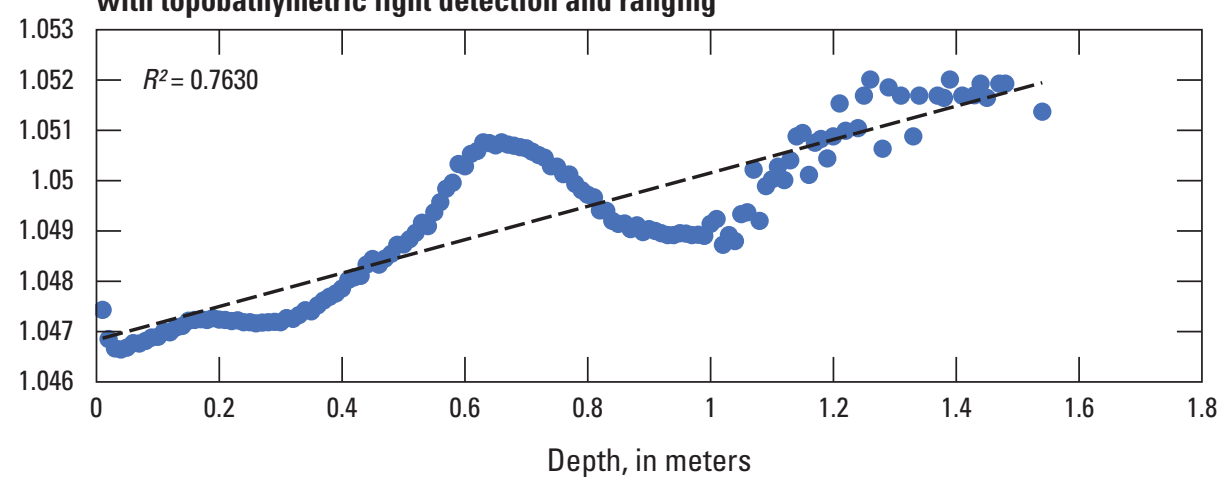

EXPLANATION

$$
\begin{aligned}
& \text { - - - - Trendline } \\
& R^{2}=0.7630 \quad \text { Coefficient of determination }
\end{aligned}
$$

Figure 2. Comparison between satellite imagery (Landsat 8 Operational Land Imager, Sentinel-2B, WorldView-3, and Landsat 8 Provisional Aquatic Reflectance science product) correlations and topobathymetric light detection and ranging. 


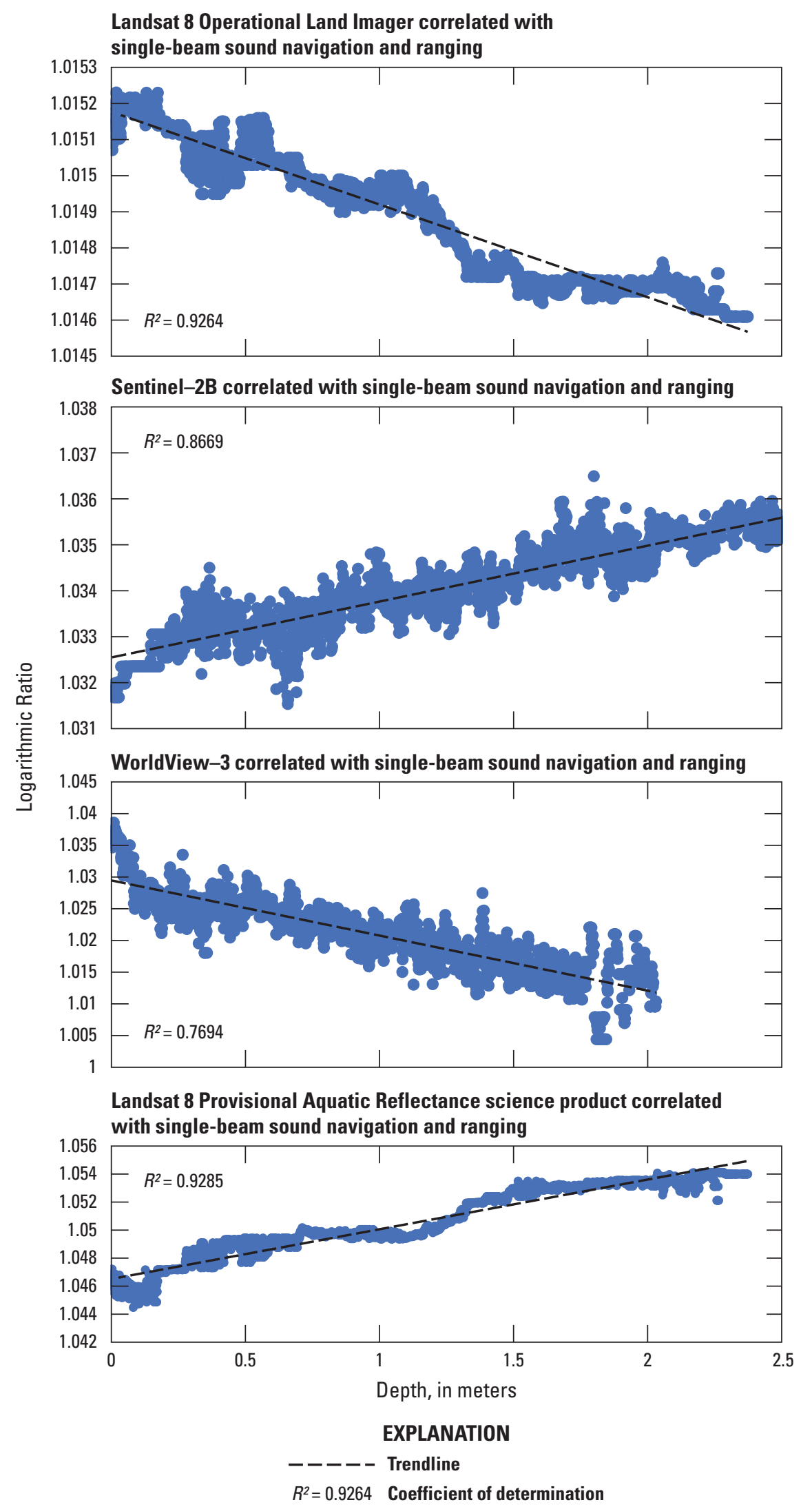

Figure 3. Comparison between satellite imagery (Landsat 8 Operational Land Imager, Sentinel-2B, WorldView-3, and Landsat 8 Provisional Aquatic Reflectance science product) correlations and nearshore single-beam sound navigation and ranging. 

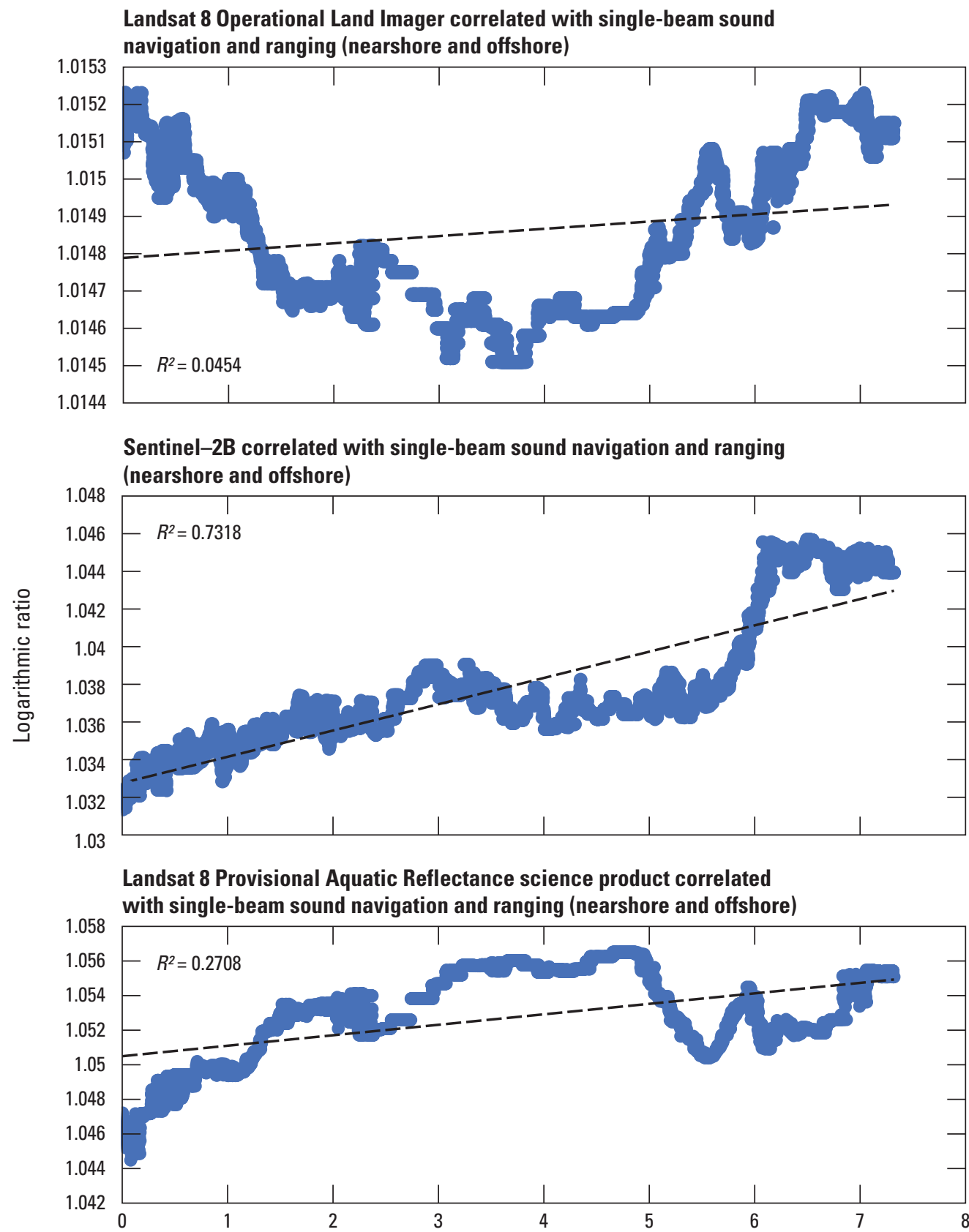

Depth, in meters

EXPLANATION

$$
\begin{array}{ll}
--ー-- & \text { Trendline } \\
R^{2}=0.0454 & \text { Coefficient of determination }
\end{array}
$$

Figure 4. Comparison between satellite imagery (Landsat 8 Operational Land Imager, Sentinel-2B, and Landsat 8 Provisional Aquatic Reflectance science product) correlations, and nearshore and offshore single-beam sound navigation and ranging. WorldView-3 correlation was not applicable because sound navigation and ranging offshore depths were beyond the WorldView-3 extent. 


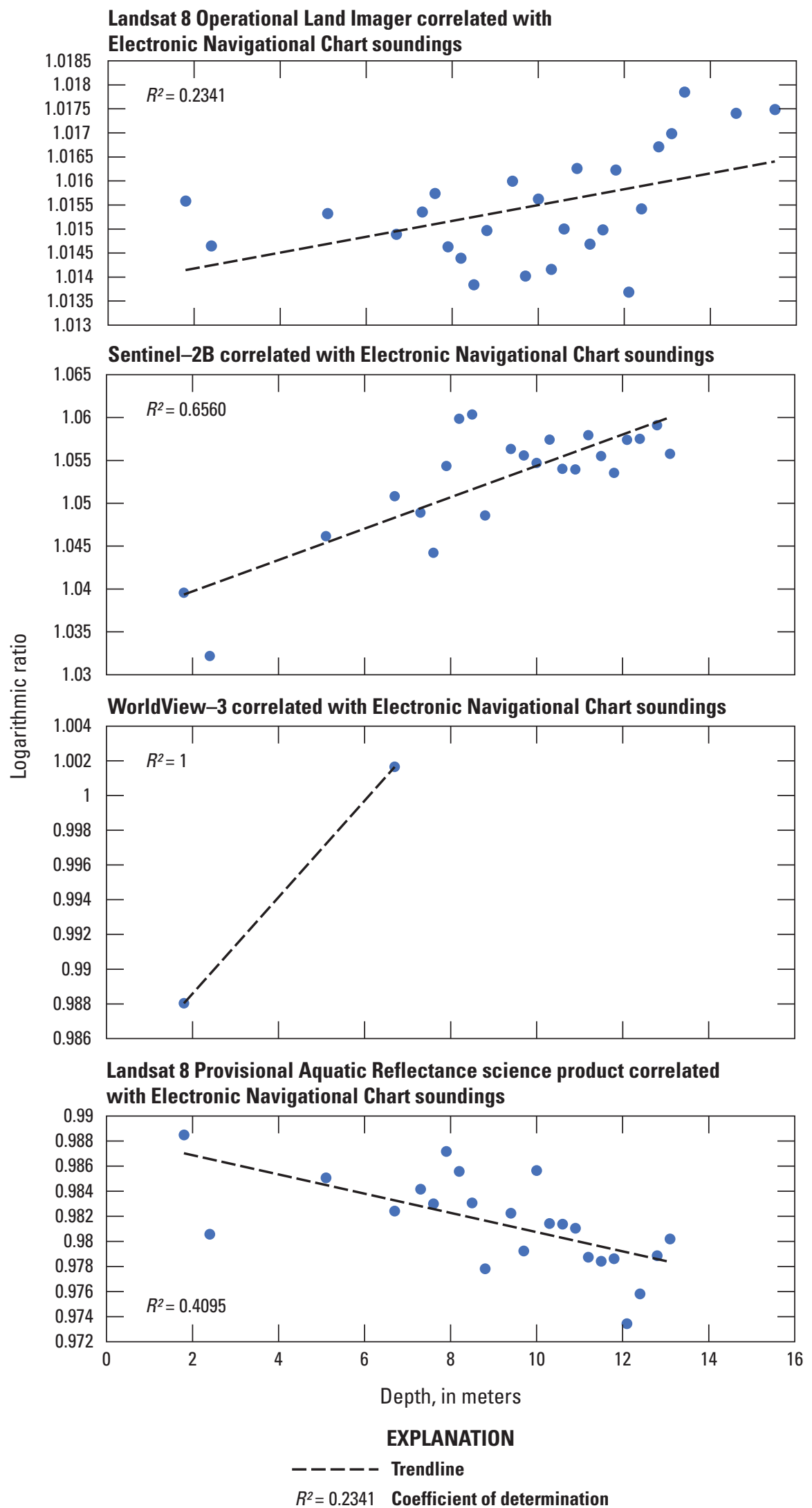

Figure 5. Comparison between satellite imagery (Landsat 8 Operational Land Imager, Sentinel-2B, WorldView-3, and Landsat 8 Provisional Aquatic Reflectance science product) correlations and Electronic Navigational Chart soundings. 


\section{Discussion}

The purpose of this empirical SDB study was to assess the viability of different satellite imagery for deriving nearshore bathymetry for coastal Unalakleet, Alaska. This was an ambitious goal considering that each satellite imagery was acquired from a different sensor at different viewing angles on different days at different horizontal resolutions (table 1). Each of these variables need to be considered when comparing the SDB correlation results.

In table 1, the satellite imagery horizontal resolutions vary from $30 \mathrm{~m}$ (L8 OLI and L8 Provisional AR) to $10 \mathrm{~m}$ (Sentinel-2B) to $2 \mathrm{~m}$ (WV-3). Thus, any comparison of the SDB correlations should factor in the differences between satellite imagery horizontal resolutions. As shown in figures 2-4, the higher resolution imagery did not always provide the best $R^{2}$ in some of the correlations, which may be caused by the off-nadir viewing angle (table 1).

Temporal acquisition dates for the satellite imagery, topobathy lidar, and single-beam sonar are another consideration when comparing the SDB correlations. To minimize temporal differences, the search for cloud-free satellite imagery centered around the topobathy lidar and single-beam sonar acquisition dates (July 2019) because the SDB band ratio values were correlated with those data. However, the availability for cloud-free L8 imagery over the study area was in April 2019 (table 1), a few months before the July 2019 lidar and sonar acquisitions (table 2). Cloud-free imagery was available for Sentinel-2B and WV-3 imagery in the July 2019 timeframe (table 1).

In addition to the temporal aspect of the SDB study, the geographical extent of the topobathy lidar and single-beam sonar data was important as well. For example, the topobathy lidar and single-beam sonar boundary extents were different. The topobathy lidar dataset contained nearshore depths as much as about $1.5 \mathrm{~m}$, but the acquisition did not extend as far into the water as the single-beam sonar acquisition, which contained two transects as much as $7 \mathrm{~m}$ deep. Therefore, two sonar subsets were created: one subset with nearshore soundings only; and another sonar subset with nearshore and offshore soundings as much as about $7 \mathrm{~m}$. Both sonar subsets were correlated with SDB band ratio values to test if the deeper soundings (about $7 \mathrm{~m}$ ) would provide a better correlation. However, as shown in figures $2-5$, ancillary data subsets created from geographic locations can result in a different $R^{2}$ for each correlation (some even lower than expected, especially for observed satellite reflectance). To achieve correlation consistency, ancillary subsets were selected from a geographic location near the inflection point line, which was used to determine the delineation between water and land in the satellite imagery. The same topobathy lidar and single-beam sonar subsets were used in all correlations. Also, it should be noted that the WV-3 satellite sensor, although collecting at a higher resolution image, does not have as wide of a swath width as
L8 or Sentinel-2B sensors. Therefore, the WV-3 imagery selected for this SDB study did not extend far enough into the water to correlate with the second sonar subset.

For the empirical band ratio method used in this study, an extinction depth is usually identified so that linear regression equations can be applied to band ratios values to derive calibrated SDB. However, defining an extinction depth in the correlations was problematic because of the shallow depths within the extents of the topobathy lidar and single-beam sonar (figs. 2-5). This does not imply that either of the ancillary datasets were not viable for correlation purposes; rather, it may imply that the low $R^{2}$ in the correlations are due to low-lying shallow waters in a community negatively affected by erosion from the Unalakleet River and Norton Sound where there are turbid waters. Therefore, results indicate that potential turbidity in the observed satellite imagery radiance, reflectance, or both would need to be addressed before applying the band ratio method. Although the blue/green satellite imagery band ratio was applied in these correlations, others have addressed turbidity or high concentrations of suspended sediment by applying the band ratio to multiple pairs of satellite imagery bands, such as green/red bands or a pair of near infrared bands, or by using multitemporal satellite images to test for possible strong linear relations with ancillary data (Legleiter and others, 2009; Pe'eri and others, 2016b; Caballero and Stumpf, 2021).

\section{Summary}

Flooding, storm surge, and sea-level rise are but a few of the natural hazards that the low-lying coastal community of Unalakleet, Alaska, has been subjected to, compounded by high erosion rates stemming from the Unalakleet River to the east and the Norton Sound to the west. Furthermore, the community is situated at a high latitude alongside the Bering Sea, which exposes the low-lying area and infrastructure to historically strong winter storms. Collectively, these coastal hazard effects have led to the need for nearshore topographic and bathymetric information.

In an attempt to fill this critical data gap, an empirical satellite-derived bathymetry (SDB) method was applied to Landsat 8 (L8) Operational Land Imager (OLI), L8 Provisional Aquatic Reflectance (AR) science product, Sentinel-2B, and WorldView-3 (WV-3) satellite imagery to characterize light attenuation within the water column in the coastal waters surrounding Unalakleet, Alaska. Satellite imagery band ratio calculations were performed to derive vertical profile estimates. By correlating imagery band ratios from passive satellite sensors with airborne topobathymetric (topobathy) light detection and ranging (lidar) and in situ singlebeam sound navigation and ranging (sonar) collected with watercraft equipped with active sensors, the linear regressions were assessed to determine which satellite imagery was viable for deriving nearshore bathymetry for coastal Unalakleet, 
Alaska. This study is one of the first attempts to compare different satellite imagery correlations with topobathy lidar and in situ sonar to assess the viability for nearshore SDB in the context of the low-lying coastal Unalakleet, Alaska, community vulnerable to natural hazards.

The topobathy lidar correlations with L8 OLI, Sentinel-2B, WV-3, and L8 Provisional AR satellite imagery showed similar linear regressions patterns, but few yielded a strong linear relation with the water depths. An extinction depth was not identified because the topobathy lidar acquisition did not extend beyond about 1.5 meters deep. The coefficient of determination $\left(R^{2}\right)$ values for topobathy lidar correlation were 0.7955 for L8 OLI, 0.7922 for Sentinel-2B, 0.7060 for WV-3, and 0.7630 for L8 Provisional AR science product. All topobathy lidar correlations with satellite imagery exhibited a dispersed linear regression pattern beyond 1 meter.

The in situ single-beam sonar correlations with L8 OLI, Sentinel-2B, WV-3, and L8 Provisional AR satellite imagery showed stronger linear relations with the water depths than the topobathy lidar. Although the nearshore soundings did not extend beyond about 3 meters, the $R^{2}$ values for singlebeam sonar correlation were 0.9264 for L8 OLI, 0.8669 for Sentinel-2B, 0.7694 for WV-3, and 0.9285 for L8 Provisional AR science product. When nearshore (as much as about 3 meters deep) and offshore single-beam soundings (as much as about 7 meters deep) were correlated with the same imagery, the linear relation with the water depths dropped substantially (L8 OLI $R^{2}$ was 0.0454 ; Sentinel-2B $R^{2}$ was 0.7318 ; and L8 Provisional AR science product $R^{2}$ was 0.2708 ). Because the sonar offshore depths were beyond the WV-3 imagery extent, a correlation was not performed. For the single-beam sonar correlations with satellite imagery band ratios, an extinction depth was not identified because of the shallow depth of the nearshore sounding correlations or the lower $R^{2}$ linear regressions with the nearshore and offshore sounding correlations.

Available soundings in the Electronic Navigational Chart were from older source data for the Unalakleet, Alaska, nearshore area. Therefore, the correlations with L8 OLI, Sentinel-2B, WV-3, and L8 Provisional AR science product satellite imagery did not yield a strong linear relation with the water depths because the Electronic Navigational Chart soundings dated back to the early 20th century.

As correlations were performed, it became evident that neither the satellite imagery temporal and resolution differences nor the ancillary topobathy lidar and in situ single-beam sonar extents were exclusively the cause of less-than-optimal linear regression results. Although some correlations yielded a stronger linear relation with the water depths (higher $R^{2}$ ) than others, several variables need to be considered when comparing the SDB correlation results, including the geography of Unalakleet, Alaska, a low-lying coastal community subject to flooding, storm surge, strong storms, and erosion from turbid waters.

\section{References Cited}

Caballero, I., and Stumpf, R.P., 2021, On the use of Sentinel-2 satellites and lidar surveys for the change detection of shallow bathymetry - The case study of North Carolina inlets: Coastal Engineering, v. 169, p. 103936. [Also available at https://doi.org/10.1016/j.coastaleng.2021.103936.]

City of Unalakleet, 2008, Local Hazards Mitigation Plan (rev. June 30, 2008): City of Unalakleet, 76 p., accessed September 18, 2020, at https://climate.law.columbia.edu/ content/adaptation-plans.

Danielson, J.J., Poppenga, S.K., Brock, J.C., Evans, G.A., Tyler, D.J., Gesch, D.B., Thatcher, C.A., and Barras, J.A., 2016, Topobathymetric Elevation Model Development using a New Methodology-Coastal National Elevation Database: Journal of Coastal Research, v. 76, p. 75-89. [Also available at https://doi.org/10.2112/SI76-008.]

DigitalGlobe, 2016, WorldView-3: DigitalGlobe data sheet, 2 p., accessed October 5, 2020 at http://satimagingcorp.s3. amazonaws.com/site/pdf/WorldView3-DS-WV3-Web.pdf.

Erikson, L.H., McCall, R.T., van Rooijen, A., and Norris, B., 2015, Hindcast storm events in the Bering Sea for the St. Lawrence Island and Unalakleet regions, Alaska: U.S. Geological Survey Open-File Report 2015-1193, 47 p. [Also available at https://doi.org/10.3133/ofr20151193.]

European Space Agency, 2020a, Missions, Sentinel-2: ESA Sentinel Online web page, accessed August 6, 2020, at https://sentinel.esa.int/web/sentinel/missions/sentinel-2.

European Space Agency, 2020b, User guides, Sentinel-2 MSI introduction, resolutions, radiometric resolutions: ESA Sentinel Online web page, accessed August 6, 2020, at https://sentinel.esa.int/web/sentinel/user-guides/sentinel-2$\mathrm{msi} /$ resolutions/radiometric.

International Hydrographic Organization, 2019, The IHOIOC GEBCO cook book: International Hydrographic Organization (IHO) Publication B-11, Intergovernmental Oceanographic Commission (IOC) Manuals and Guides 63, 493 p., accessed September 22, 2020, at https://www.star. nesdis.noaa.gov/socd/lsa/GEBCO_Cookbook/.

Legleiter, C.J., and Overstreet, B.T., 2012, Mapping gravel bed river bathymetry from space: Journal of Geophysical Research, v. 117. [Also available at https://doi.org/10.1029/ 2012JF002539.]

Legleiter, C.J., Roberts, D.A., and Lawrence, R.L., 2009, Spectrally based remote sensing of river bathymetry: Earth Surface Processes and Landforms, v. 34, p. 1039-1059. [Also available at https://doi.org/10.1002/esp.1787.] 
National Oceanic and Atmospheric Administration [NOAA], 2018, NOAA Alaska - West coast, Norton Sound to Bering Strait raster navigational chart 16200 (16th ed.): Office of Coast Survey, accessed July 13, 2020, at https://www.charts. noaa.gov/InteractiveCatalog/nrnc.shtml.

National Oceanic and Atmospheric Administration [NOAA], 2019a, Digital Coast Data Access Viewer, custom processing of 2019 USACE NCMP topobathy lidar-Alaska: Charleston, S.C., National Oceanic and Atmospheric Administration Office for Coastal Management, accessed September 17, 2020, at https://coast.noaa.gov/dataviewer.

National Oceanic and Atmospheric Administration [NOAA], 2019b, Transforming the NOAA ENC-Implementing the national charting plan (rev. November 7, 2020): Office of Coast Survey, 12 p., accessed July 13, 2020, at https://nauticalcharts.noaa.gov/publications/docs/enctransformation.pdf.

National Oceanic and Atmospheric Administration [NOAA], 2020, NOAA Electronic Navigational Chart US3AK80M (11.1th ed.): Office of Coast Survey, accessed July 13, 2020, at https://www.charts.noaa.gov/InteractiveCatalog/ nrnc.shtml.

Patton, W.W., Jr., and Moll-Stalcup, E.J., 1996, Geologic map of the Unalakleet quadrangle, west-central Alaska: U.S. Geological Survey Miscellaneous Investigations Series Map I-2559, scale 1:250,000, 39 p., https://dggs.alaska.gov/ pubs/id/12904.

Pe'eri, S., Madore, B., Alexander, L., Parrish, C., Armstrong, A., Azuike, C., and Tetteh, E., 2016a, LANDSAT 8 satellitederived bathymetry, chap. 11 in The IHO-IOC GEBCO Cook Book: International Hydrographic Organization (IHO) Publication B-11, Intergovernmental Oceanographic Commission (IOC) Manuals and Guides 63, p. 243-304, accessed December 2016 at https://www.star.nesdis .noaa.gov/socd/lsa/GEBCO_Cookbook/.

Pe'eri, S., Madore, B., Nyberg, J., Snyder, L., Parrish, C., and Smith, S., 2016b, Identifying bathymetric differences over Alaska's north slope using a satellite-derived bathymetry multi-temporal approach: Journal of Coastal Research, v. 76, p. 56-63. [Also available at https://doi.org/10.2112/ SI76-006.]

Poppenga, S.K., Palaseanu-Lovejoy, M., Gesch, D.B., Danielson, J.J., and Tyler, D.J., 2018, Evaluating the potential for near-shore bathymetry on the Majuro Atoll, Republic of the Marshall Islands, using Landsat 8 and WorldView-3 imagery: U.S. Geological Survey Scientific Investigations Report 2018-5024, 14 p. [Also available at https://doi.org/ 10.3133/sir20185024.]
Snyder, A.G., and Gibbs, A.E., 2019, National assessment of shoreline change-A GIS compilation of updated vector shorelines and associated shoreline change data for the north coast of Alaska, Icy Cape to Cape Prince of Wales: U.S. Geological Survey data release, https://doi.org/ 10.5066/P9H1S1PV.

Snyder, A.G., Johnson, C.D., Gibbs, A.E., and Erikson, L.H., 2021, Nearshore bathymetry data from the Unalakleet River mouth, Alaska, 2019: U.S. Geological Survey data release, https://doi.org/10.5066/P9238F8K.

Stumpf, R.P., Holderied, K., and Sinclair, M., 2003, Determination of water depth with high-resolution satellite imagery over variable bottom types: Limnology and Oceanography, v. 48, no. 1, p. 547-556. [Also available at https://doi.org/10.4319/lo.2003.48.1_part_2.0547.]

Thatcher, C.A., Brock, J.C., Danielson, J.J., Poppenga, S.K., Gesch, D.B., Palaseanu-Lovejoy, M.E., Barras, J.A., Evans, G.A., and Gibbs, A.E., 2016, Creating a Coastal National Elevation Database (CoNED) for science and conservation applications: Journal of Coastal Research, v. 76, p. 64-74. [Also available at https://doi.org/10.2112/SI76-007.]

U.S. Army Corps of Engineers, [USACE], 2006, Alaska Village Technical Assistance Program-An examination of erosional issues in the communities of Bethel, Dillingham, Kaktovik, Kivalina, Newtok, Shishmaref, and Unalakleet: U.S. Army Corps of Engineers Alaska District, 44 p., accessed September 17, 2020, at http://66.160.145.48/coms/ cli/AVETA_Report.pdf.

U.S. Army Corps of Engineers, [USACE], 2019, Condition of improvements, 31 December 2019, Unalakleet erosion control, Alaska: U.S. Army Corps of Engineers CWIS No. 081818, 181723, and 337747, 8 p., accessed September 17, 2020, at https://www.poa.usace.army.mil/Portals/34/docs/ operations/EFC/2019UnalakleetOverview.pdf?ver=202004-30-171847-867.

U.S. Geological Survey [USGS], 2016, Landsat-Earth observation satellites (ver. 1.1, August 2016): U.S. Geological Survey Fact Sheet 2015-3081, 4 p., accessed October 5, 2020, at https://doi.org/10.3133/fs20153081.

U.S. Geological Survey, [USGS], 2019a, DigitalGlobe WorldView-3 multispectral imagery, July 7, 2019: U.S. Geological Survey EarthExplorer web page, accessed July 8, 2020, at https://earthexplorer.usgs.gov.

U.S. Geological Survey, [USGS], 2019b, Landsat 8 multispectral imagery, April 24, 2019: U.S. Geological Survey EarthExplorer web page, accessed July 7, 2020, at https://earthexplorer.usgs.gov. 
U.S. Geological Survey, [USGS], 2019c, Sentinel-2B multispectral imagery, July 7, 2019: U.S. Geological Survey EarthExplorer web page, accessed August 6, 2020, at https://earthexplorer.usgs.gov.

U.S. Geological Survey, [USGS], 2020a, EROS Science Processing Architecture on demand interface:

U.S. Geological Survey digital data, accessed July 14, 2020, at https://espa.cr.usgs.gov/.

U.S. Geological Survey, [USGS], 2020b, Landsat Provisional Aquatic Reflectance Product Guide, LSDS-1422 (ver. 1.0): Reston, Va., U.S. Geological Survey, 24 p., accessed June 10, 2021, at https://www.usgs.gov/media/files/landsatprovisional-aquatic-reflectance-product-guide.
U.S. Geological Survey, [USGS], 2020c, Landsat science products - Landsat Provisional Aquatic Reflectance: U.S. Geological Survey, accessed July 14, 2020, at https://www.usgs.gov/core-science-systems/nli/landsat/ landsat-provisional-aquatic-reflectance.

U.S. Geological Survey, [USGS], 2020d, Using video imagery to study wave dynamics - Unalakleet: U.S. Geological Survey, Pacific Coastal and Marine Science Center web page, accessed September 17, 2020, at https://www. usgs.gov/centers/pcmsc/science/using-video-imagery-studywave-dynamics-unalakleet?qt-science_center_objects= 0\#qt-science_center_objects.

Wilson, F.H., Hults, C.P., Mull, C.G., and Karl, S.M., comps., 2015, Geologic map of Alaska: U.S. Geological Survey Scientific Investigations Map 3340, 197 p., 2 sheets, scale 1:584,000. [Also available at https://doi.org/10.3133/ $\operatorname{sim} 3340$. 

For more information about this publication, contact: Director, USGS Earth Resources Observation and Science Center 47914 252nd Street

Sioux Falls, SD 57198

605-594-6151

For additional information, visit: https://www.usgs.gov/centers/eros

Publishing support provided by the

Indianapolis, Lafayette, and Rolla Publishing Service Centers 


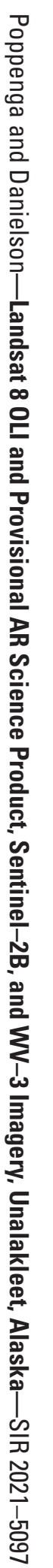

